\title{
HISTORICAL BASES OF THE FEDERAL JUDICIAL SYSTEM*
}

\author{
JoHN P. Frank
}

When James Madison and fifty-four other gentlemen met in Philadelphia in May, 1787, they had a number of questions on their minds more important to them than a federal judiciary. Protection of commerce against disruption by state taxes or regulations, an end to impairment of contracts, a taxing system equal to the public needs, an executive department-these were burning necessities to the fifty-five. Discussion in the country during the period of ratification usually found livelier topics than courts or judges. Indeed, except for a vigorous attack on the lack of a requirement for a civil jury and less ardent attacks on diversity, the judiciary clauses were almost immune from strenuous criticism or discussion.

In short, while there was in 1787 a felt need for a federal judiciary, it was not an overwhelming need. The contract clause had its Shay's Rebellion, the prohibition of state coinage had its state tender laws, the Senate and the House had their Great Compromise, the prohibition on state tariffs had its history of state tariffs. ${ }^{2}$ Similarly

- Parts I and II of this essay will briefly synthesize developments which preceded the adoption of the judiciary article of the Constitution. Part III briefly states and explores certain theories, some very tentative, as to the origin of particular jurisdictional clauses. The origins of judicial review are outside the scope of this article. Leading historical works on that subject are Charles G. Haines, American Doctrine of Judicial Suprearacy (1932); Chardes A. Beard, The Supreme Court and the ConstiTUtron (1912); and articles collected in I SELEcted Essays on Constituttonal LAw I-174 (1938).

+ B.A. 1938, University of Wisconsin; LL.B. and M.A. 1940, University of Wisconsin; J.S.D. 1947, Yale University. Member of the Wisconsin and United States Supreme Court bars. Assistant Professor of Law, Indiana University. Professor Frank desires to express his appreciation for assistance to Mr. Charles Gaus, Mr. Raymond Sweat, and Mr. Robert Walsman, students in his seminar in American Legal History.

1 There were three principal sources of opposition to the judiciary portions of the Constitution: First, the lack of a guarantee of jury trial in civil cases; second, the provision giving the Supreme Court appellate jurisdiction "both as to Law and Fact"; and third, the diversity provisions. Patrick Henry's denunciation of the Constitution for its lack of a civil jury guarantee is typical of countless expressions of that objection. 3 Elliort's Constitutional Debates 5.14, 545 (IgOI), hereafter cited as Elziott. The "and Fact" objection was closely related, and was based on the assumption that the Court was thus empowered to ignore if it chose the findings of juries. For example of this fear, see Lee, Letters of a Federal Farnier, in Paul L. Ford, Pampintets on the Constiturion, 294, 308 (1888). Edmund Pendleton, Chief Justice of the Virginia Court of Appeals, was, in the opinion of Madison and Washington, the most effective supporter of the Constitution in the Virginia convention; RoBERT L. Hilldrup, Life and Times of Edmund Pendeton 280 (1939). Of the "and Fact" phrase, Pendleton said, "Though I dread no danger, I wish these words had been buried in oblivion. If they had, it would have silenced the greatest objections against the section." 3 ELLIorT 5Ig. The Seventh Amendment was intended to allay the foregoing fears. The many criticisms of diversity jurisdiction were primarily aimed at the fear that litigants would be required to travel great distances and litigate at great expense. Sec, for example, Lee in ForD, supra, at 308. Both Massachusetts and New Hampshire recommended sharp limitations on the diversity jurisdiction. I ELLroTr 322, 323, 326. Yet this discussion must be seen in proportion. 3 Correspondence and Pubzic PApers of Jorn JAY (189r) discusses the adoption of the Constitution at length and makes no appreciable mention of the judiciary. Neither does ERNEST W. Spaulding, His Excellency George Clinton (1938), although Clinton was a leading opponent of the Constitution in New York.

'One of the many accounts of the Constitution with analyses of these problems is in I SAMUEL E. Morison and Henry S. Commager, The Growth of the American Repuglic, cc. 12 and 13 (1942). 
the judicial system is in part the product of single definite episodes, but in part precise causes may never be found because they lie no deeper than the common sense of the Committee on Detail of the Constitutional Convention. In this history it is sometimes easier to find predecessors than origins.

\section{I}

\section{The EARLIER Systems}

\section{A. Colonial General Courts ${ }^{3}$}

The thirteen colonies of course had differences in the structure of their legal systems, but certain basic general features stand out. The colonies usually began with a system of complete executive, legislative, and judicial power merged in a central dominant official, as in early Virginia, ${ }^{4}$ or group, as in Massachusetts. ${ }^{5}$ As pressure of business and the spread of population compelled it, the judicial business fell into specialized hands, and local or regional courts were established. Appeals from local courts to the governor or council or to the colonial legislature were common, with final appeal to the Privy Council.

The justice administered in colonial courts was usually as learned and frequently as pompous as its practitioners could make it. On occasion it was more pompous than learned. ${ }^{6}$ A few colonial lawyers studied in England, but only a few, and the largest law library in New York early in the eighteenth century contained 152 volumes. ${ }^{7}$ A Maryland court in $\mathbf{1 7 7 2}$, overcome with the difficulty of a problem, referred it to those lawyers lounging about the court room for solution, ${ }^{8}$ and a traveler in seventeenth-century Virginia noted that "a liberal supply of strong drink often makes Justice nod and drop the scales."

A description of the system in Virginia suggests the commonly met problems. ${ }^{10}$

\footnotetext{
sor a detailed study of court structure in each colony, see Roscoe Pound, Oranization op Counts 26-90 (1940). The most extensive study of one system is Julius Goebel and T. R. Nauguton, Law ENForcement in Colonint New YoRK (1944).

' Chitwood, Justice in Colonial Virginia, in 23 Jorss Hopxiss Univ. Studes in Hist. ANd Pot. Sct. 13 (rg05).

"For an account of the Massachusetts system, see Williak T. DAvis, History of thHe Judiciary OF MASSACHUSETTS I-I75 (I900). Merger of functions is a common aspect of colonial societies which lack enough - personnel for divided government or enough business to warrant it. Simultancously with American development, the same phenomenon was occurring under Dutch rule in South Africa. W. P. M. Kennedy and H. J. Schlosberg, The Law and Custom of the South African Constitution 5-8 (r935).

${ }^{6}$ McMillen, County Courts of Coloniaz Virgivia it (unpublished thesis in Indiana University Library, I935).

${ }^{7}$ Paul M. Hamlin, Legar Education in Colonial New York 76 (1939). Hamlin, who has written a very interesting description of this subject, says that 236 members of the New York bar before 1815 had studied at the Inns of Court, most of them after the Revolution. Id. at 17, 18. Apprenticeship in an English office cost from $£ 200$ to $£_{300}$ for five years. Id. at 2 (n. 35 ), 33.

${ }^{8}$ Nicholson v. Sligh, $\mathrm{I}$ H. \& $\mathrm{McH}$. (Md.) 434 (1772). On the untrained New Hampshire judges, see Paul S. Reinsch, Exglish Common Law in the Eariy American Colonies 27, 28 (1899).

McMrnten, op. cit. supra, note 6, at r2, quoting Colonel William Byrd.

${ }^{10}$ The following two paragraphs are drawn from Chitwood, sttpra note 4 , and McMillen, op. cif. supra, note 6; George L. Chumbley, Colonial Justice in Virginia (1938); and Watter B. Richands, Genesis of the Federaz Judictal Srstem I5 (Address, Virginia State Bar Association (1904), pamphlet in the Library of Congress).
} 
Justice was originally declared by a Council, replaced in a few years by a Governor. The gross cruelties of administration between 16 io and I6rg by Lord de la Warr and Governor Dale were followed by a transfer of supreme judicial power to the Assembly, where it remained until $\mathbf{1 6 8 2 .}$. Then the legislative judicial authority ended, supplanted by a "General Court" consisting of the Governor and his Council, which he appointed.

Yet from the beginning regional courts were necessary, and the "monthly court" system was created in 1624 and became the county court system in 1643 . These courts, composed usually of eight members, decided local cases by majority vote and also had extensive administrative duties, such as making tax assessments, appointing inspectors to receive wolf heads from the Indians for bounty, and fixing prices at local taverns. In the eighteenth century these courts were supplemented by magistrate's courts of single justices to handle cases up to twenty-five shillings. Appeals in civil cases could be taken up the scale of courts and eventually to England if progressively larger sums of money or tobacco were involved. In addition to these three courts, there were also courts of hustings, a court of oyer and terminer, special slave courts, and the Court of the Commissary of the Bishop of London. ${ }^{11}$

Even so brief a sketch as this suggests certain basic features of the early colonial court system: (I) The courts went to the people; (2) courts were part of an amalgamated system of government with no rigid separation of executive, legislative, and judicial functions; (3) the accessibility of particular courts depended in civil cases on the amount involved; ${ }^{12}$ (4) the colonists were conditioned to a great number of courts and an elaborate system of appeals.

\section{B. Privy Council}

The most significant aspect of Privy Council review of colonial legal problems is that, by virtue of the Council's double jurisdiction, it merged into one body the systems of both judicial and legislative review. ${ }^{13}$ It could disapprove of statutes by veto and could also invalidate a colonial statute in the course of deciding a case. A foremost example was the invalidation of the Connecticut intestacy distribution statute because it conflicted with common-law conceptions of primogeniture. ${ }^{14}$ The

${ }^{2 x}$ Chitwood, stpra note 4 , at 70 , reports that the Bishop's court had jurisdiction of offenses by the clergy; but this jurisdiction could not have been exclusive, for the church wardens and vestrymen proceeded in general court against a delinquent clergyman who allegedly "cared not of what religion he was so that he got the tobacco, nor what became of the flock so that he could get the fleece." Goodwin v. Lunan, Jeff. Va. Rep. 96,97 (177I).

${ }^{22}$ In sharp contradistinction to our present federal system, however, appeals also depended primarily on the amount involved.

${ }^{13}$ For discussion, see I Charles G. Haines, American Doctrine of Judicial Supremacy 44-66 (2d. ed. 1932). For extensive studies of the appellate work of the Privy Council, see Hazeltine, Appeals from Colonial Courts to the King in Council with Especial Reference to Rhode Island, ANN. REP. AM. Hist. Ass's 323 (I894); Schlesinger, Colonial Appeals to the Prity Council, 28 Por. Scr. Q. 440 (1913); Kellogg, The American Colonial Charter, I Ann. Rep. AM. Hist. Ass'N I87, 267 (I903); 3 Herbert L. Osgood, Axerican Colonies, I8th Century 304-307 (1924).

16 An easy-to-read account of the case is James Truslow Adams, Revolutionary New England, $1691-1776126-130$ (1923). 
jurisdictional amount, set at $£_{3} 300$ in 1753 in particular types of cases, ${ }^{15}$ none the less left the Council with a sizable jurisdiction.

It is the general and unchallenged opinion of scholars that the Privy Council system is a real antecedent of the modern Supreme Court and the modern system of judicial review. ${ }^{16}$ Jefferson desired in 1787 that the Supreme Court should be part of a "Council" with a general veto over legislation. ${ }^{17}$ Jefferson did not then, of course, anticipate that his views of the judiciary would change when he knew Marshall better, but it may surely be hazarded that he was led to his initial impulse by his acceptance of the Privy Council system.

The Privy Council served a more important function than that of review of legislation. It also heard border disputes between the colonies. In our own placid acceptance of the federal system, we are accustomed to think of state rivalries being settled from year to year on the gridirons of state universities; but in the r780's unsettled border disputes would have meant war. The Privy Council settled at least nine such disputes, ${ }^{18}$ and the removal of its service as arbiter left a void which was filled clumsily under the Confederation and conclusively by the Constitution.

$$
\text { C. Admiralty }
$$

It was absolutely imperative that the problems normally decided by admiralty courts be decided by someone, and admiralty courts were among the first established in the colonies. ${ }^{19}$ Admiralty courts had begun in England in the fourteenth century, and as early as 1360 Sir John Beauchamp was given authority to try pirates, ${ }^{20}$ a problem thereafter existing in both hemispheres. ${ }^{21}$ The first admiralty court in North America was established in Newfoundland in 1615 when Sir Richard Whitbourne was given authority as admiral to punish Sabbath breaking, fouling the fairways, and burning forests ashore. The first case in Massachusetts occurred in I630 when Thomas Moulton, pilot, chose between flogging and a forty-shilling fine for deserting his ship at Plymouth.

In the seventeenth century a system of vice-admiralty courts, dominated by the colonial governors, spread through the colonies. They had then and retained later two primary types of jurisdiction: (I) ordinary marine cases, including wages and

\footnotetext{
15 I Leonard W. Labaree, Royal Instructions to British Colontal Governors, No. 453, 325-327, and see 329 (1935).

${ }^{10}$ See, for example, James B. Thayer, Legal Essays I, 3 (I908); I Homer C. Hockett, The Constitutional History of the UNITED States 155 (r939).

${ }^{17}$ Letter, Jefferson to Madison, December 20, 1787, IV Doc. Historx of trie Constitution 411 (Dep't State I905), cited hereafter as Doc. Hist.

${ }^{28}$ Discussed briefly in 1 Hockert, op. cit. stupra, note 16 , at 155 , and in Sargeant's essay in DuponCEAU, JURISDICTION I4I (I824).

${ }_{10}$ Two leading studies of colonial admiralty courts are Charles MeL. Andrews, Vice Admiralty Courrs in the Colonies, in Dorothy S. Towle, Recoros of the Vice Admralty Court of Rhode Istand, 1716-1752 I-79 (1936); and Helen Crump, Colonial Admiralty Jurisdiction in the 17t7i Century, Royal Earpire Social Study No. 5 (London, 1931). Other authorities are collected in Hendry Co. v. Moore, 318 U. S. 133,137, n. 1, and 144, n. 6 (r943).

so The references in this paragraph are taken from CRUMP, op. cit. supra, note 19, c. 1 .

${ }^{21}$ For documents on piracy, see John F. Jameson, Privateering and Piracy in the Colonial Period (1923). Pages $190-257$, e.g., contain the papers in the case of Captain Kidd.
} 
salvage; and (2) prize cases. ${ }^{22}$ However, in the latter portion of the seventeenth century Britain began to enforce her navigation and trade acts against the colonies, a step which led directly to reorganization of the admiralty courts.

In England, forfeitures for violation of revenue or navigation laws were heard not in admiralty, but in Exchequer. Experience in the colonies proved that juries would not convict their fellow colonials in trade cases, ${ }^{23}$ and in 1697 the admiralty courts were reorganized to utilize their non-jury procedures in the colonies to enforce the acts of trade. The gubernatorial control was eliminated, and the vice-admiralty courts became Crown courts with added trade jurisdiction. ${ }^{24}$

The result was the emergence of a new type of admiralty court in the colonies from which appeals lay first to the High Court of Admiralty ${ }^{25}$ and, near the end of the colonial period, to the Privy Council.26 Developments in these new courts were not uniform, but they were trending in a distinctly non-English direction, a historical fact to which the Supreme Court has recently failed to give sufficient weight. ${ }^{27}$

The admiralty system retained a qualified popularity in the colonies despite the extreme dissatisfaction with the utilization of those courts for trade control. Efforts made in colonial times to establish juries in admiralty were blocked by the Privy Council, ${ }^{28}$ but several of the states during the Revolution did add juries. The real dissatisfaction with admiralty courts, however, was apparently with the law they enforced rather than their procedure, for the attempt to engraft a jury system did not survive the Constitution. ${ }^{29}$

\section{The Confederation}

The Revolution eliminated those two essential portions of the American legal system which were dependent wholly on England: the Privy Council disposition of cases between states, and the vice-admiralty courts. The latter, particularly in wartime, required a substitute.

The Revolution began under the aegis of the Continental Congress, which was legally no more than a conclave of ambassadors of independent states. One of the

22 These are discussed extensively in ANDREws, op. cit. stpra, note 19 , at 24-59.

${ }^{23} \mathrm{Id}$. at 74 .

${ }^{24}$ For discussion in addition to Andrews, see 1 H. L. Carson, History of the Supreme Court of the United States 27-38 (1905), hereafter referred to as CARson.

${ }^{28}$ Thus the High Court of Admiralty had jurisdiction over a class of appeals coming from the Colonies which it could not have heard in cases arising in England. The Vrouw Dorothea (1754), reported in The Fabius, 2 C. Rob. 245, 165 Eng. Rep. 304 (1800).

20 Andrews, op. cit. supra, note 19 , at 22 .

${ }^{27}$ Hendry Co. v. Moore, 318 U. S. 133 (I943), holding that a state court had jurisdiction to condemn a fish net used in violation of state law. It had theretofore been thought that all maritime causes of action in rem must be brought in admiralty.

${ }^{28}$ ANDrews, op. cit: supra, note $\mathrm{r} 9$, at 9 , 10 .

${ }^{20}$ See 59 , Judiciary Act, I789, I STAT. 77. It would be interesting to know exactly why juries were considered so unsuitable for admiralty. The Governor of Providence Island (off Nicaragua) recorded in his diary that he stopped jury trials in admiralty" there in 1638 because "thes Jurors proved themselves soe absurde and ignorant as sone made me finde the miserie of trialls in these dayes. ..." JAMrson, op. cit. stipra, note $2 \mathrm{r}$, at 8 . 
first tasks of these representatives was the creation of a form of government, and the Articles of Confederation were agreed to in Congress in November, 1777, though they were not ratified until $\mathrm{I} 78 \mathrm{r}$.

In establishing a judicial system, the draftsmen of the articles had no North American precedents. The Articles of Confederation of the United Colonies of New England in 1643 had contained a commissioner system which could only by a stretch be called "judicial,"30 and Benjamin Franklin's Albany Plan of 1754 had no judicial provisions at all. ${ }^{31}$ Yet the Confederators had a void to fill.

They wrote into the articles three basic provisions for dealing with judicial problems. The Confederacy was to have authority to punish piracy, quickly delegated to state officials in practice. ${ }^{32}$ A court was established to hear appeals in admiralty cases, and an almost incredibly clumsy system for arbitrating interstate border disputes was created which was actually utilized in three cases and which averted real war between Pennsylvania and Connecticut over the Wyoming lands. ${ }^{33}$

The principal national judicial system during the Revolution was in admiralty, an oft-told story. In a word, as American vessels began to take prizes, General Washington found himself seriously distracted from military duties by pleas that he dispose of the booty. In November, I775, he asked Congress to take steps to have such cases decided, and it immediately called upon the states to create their own admiralty courts with appeals to Congress. The states did so, and appeal cases were heard first by the Congress, later by a standing committee, and finally by the Court of Appeals in Cases of Capture, the first American national court, which functioned in anticipation of and under the Confederation. ${ }^{\mathbf{3 4}}$

This admiralty system was of vital significance in the conduct of the war because it was used to permit both privateers and national vessels to cash out their prizes quickly. Congress established prize agents throughout the colonies to condemn enemy ships in admiralty courts, and occasionally a captain invading an area where

\footnotetext{
${ }^{30}$ For discussion of the United Colonies, sec Chardes M. Andrews, Colonial Selp-Government r652-1689, c. 3 (1904). Article 8 authorized the Commissioners to consult "about free and speedy passage of justice in each jurisdiction to all the confederates equally, ..." Francts Bowen, Documents of the Constitution of England and America 83 (1854); and see also Article 6, id. at 82.

32 The Plan contemplated a Grand Council to govern, inter alia, Indian trade and treaties. BowEN, op. cit. supra, note 30, at 87. For William Penn's plan for union, see Breckinridge LoNg, Genesis or THE Constitution ri3-116 (r926).

${ }^{32}$ Article IX granted authority for "appointing courts for the trial of piracies and felonies," a function delegated to the states by the Confederation Congress. I9 Jour. Cont. Conc. 354 (1912).

${ }^{\mathrm{s}}$ Article IX provided that for border disputes Congress was to create a panel of thirty-nine, from which the parties would strike alternately until thirteen were left, from which the panel should be drawn by lot. Professor Jameson has shown that this system was modeled after the English Elcction Act of 1770. In England the process of selection was known as "knocking out the brains of the committee" because each side sought to eliminate the ablest supporters of the adversary. Jameson, The Predecessor of the Supreme Court, in Essays in Constitutional History I (1889). The border dispute cases, including the Wyoming dispute in.which Connecticut enlisted the military aid of the neighboring Green Mountain Boys, are described by Jameson at page 3, and by CArson, op. cit. supra, note 24, at 66-79. Each case is described in I3I U. S., App. I-lxii (1888).

34 The leading study on this subject is Professor Jameson's essay, stipra note 33. See also Carson, op. cit. supra, note 24 , cc. 4,5 .
} 
prize agents were unavailable was told to "employ some suitable attorney to libell for" his prizes. ${ }^{35}$

The system worked, but it worked poorly. The Court of Appeals and its predecessors did hear Iog cases. ${ }^{36}$ Occasionally state courts decided in favor of state interests and then refused to comply with a congressional reversal. ${ }^{37}$ Even more serious, privateers anxious to make profitable captures might seize neutral ships, and an over-zealous capture of two Spanish vessels, brought to a Massachusetts court which would not subject itself to federal review, very nearly cost the colonies the friendship of that important neutral. ${ }^{38}$ The experience of the Confederation convinced virtually every conscientious patriot of the 1780 's that the admiralty jurisdiction ought to be totally, effectively, and completely in the hands of the national government, and an extended search has not revealed a criticism from any contemporary source of the clause of the constitution granting federal admiralty jurisdiction. ${ }^{39}$

\section{II}

\section{The Inferior Federal Courts}

The Constitutional Convention had to decide whether to establish a governmental system fairly clearly divided into basic legislative, executive, and judicial departments or whether to continue the frequent colonial device of amalgamation. The oft-heard theory that the Fathers read Montesquieu, thereby misunderstood the British constitution, and as a result created the tripartite system of government, seems most unlikely. ${ }^{40}$ Madison, for example, had systematically studied the governments of the world from earliest times in anticipation of the Convention, and knew perfectly well what he was talking about. ${ }^{41}$ The evidence is that on the merits the

${ }^{36}$ This system is fully documented in OUt-Letters of THE Continental Marine Comamitien and BoArd of ADMiralty, I776-1780 (Paullin ed. Ig14), and the quotation is taken from letter to Captain John Barry, Jan. 29, 1778, Vol. 1, 198, 199.

30 13 I U. S., App. xxxv-xlix, lists the cases.

${ }^{37}$ For details see Penhallow v. Doane, 3 Dall. 54 (U. S. r795) and United States v. Judge Peters, 5 Cranch 115 (U. S. 1809).

3824 Jour. Cont. Cong. 227, 386 (1922). For account of the Massachusetts practice, see Clavde H. Van T'ine, American Revolution ig0-192 (I905).

${ }^{30}$ Privateering was a business, and the businessmen became thoroughly dissatisfied with disorderly handling of admiralty cases early in the war. In 7779 sixty-eight of the leading citizens of Philadelphia, including Robert Morris, James Wilson, and Thomas Fitzsimons, who were all to be delegates to the Constitutional Convention, petitioned for a permanent court of admiralty with fixed judges, saying, "In the privateering trade in particular, the very life of which consists in the adventurers receiving the rewards of their Success and Bravery as soon as the Cruize is over, the least delay is uncommonly destructive." Jameson, The Predecessor of the Stipreme Court, in Essays is Construturionar History 24,26 (1889).

10 For statements approaching this, see John Fiske, The Critical, Period of American History 29 r (1888); and Sir Henry Maine, in Popular Government, says, ". . neither the institution of a Supreme Court, nor the entire structure of the Constitution of the United States, were the least likely to occur to anybody's mind before the publication of the Esprit des Lois." Quoted and discussed in C. Eli.is Stevens, Sources of the Constitution of the United States I85, I86 (1894).

"Even though Federalist Paper XLVII makes him look as though he didn't, in respect to Montesquieu. For a critique of the Montesquieu theory, see Radin, The Doctrine of the Separation of Poupers in Seventeenth Century Controversies, 86 U. OF PA. I. Rev. 842 (1938). For example of Madison's extensive preparatory analysis before the Convention, see his elaborate memorandum, recopied by Washington for his own use, on contemporary and ancient governments. IV Doc. Hist. 138. 
Convention preferred divided authority and that Montesquieu was a good source of rationalization; but the choice when made was defended on the basis of colonial experience, and even so, complete separation was not the prime purpose. ${ }^{42}$

This is apparent in the history of the judiciary. The original Randolph plan provided for "one or more supreme tribunals" and a system of lower courts; but the judges were to be chosen by the legislative rather than the executive branch, and "a convenient number" of them were to participate with the Executive in a "council of revision" to veto acts of Congress. The courts were also to try impeachments. ${ }^{43}$

The disputes of the members of the Convention concerning the judiciary turned on a few questions: Should the judiciary try impeachments (a question not of interest here); how should judges be chosen, how compensated, and how long should they serve; and should there be any lower federal courts? It was accepted without question that there should be a Supreme Court.

The Randolph proposal provided for lower federal courts, and this general principle was tentatively adopted on June $4, I 787$, with no substantial discussion. ${ }^{41}$ But there was strong sentiment in the Convention to leave all litigation at the trial stage to the state courts, a principle of the competing Paterson plan, ${ }^{45}$ and on June 5 Rutledge of South Carolina moved reconsideration of the original decision by which the lower courts had been accepted. To him and to Sherman of Connecticut, appellate review by the Supreme Court was enough to protect the federal interests, and Sherman added that duplicate federal trial courts were too expensive. ${ }^{46}$

Madison opposed reconsideration, arguing that the volume of appeals would be unmanageable and that biased jury verdicts or biased trial court directions would escape any effective appellate review.

Rutledge and Sherman carried conviction to the delegates, and a motion to eliminate lower federal courts carried, five to four, with two states divided. Thereupon Madison and Wilson saw and took the opportunity for seeming compromise which eventually gave them all. The defeated Randolph proposal had required that lower courts be established; Madison and Wilson moved to give Congress the option to establish lower courts. The difference was enough to double the vote for lower courts, and the new resolution was fixed in the Constitution by a vote of eight to two.

The method of appointing judges was similarly the product of compromise. A move for exclusive executive appointment, countered by a move for exclusive legislative selection, resulted in compromise on the Massachusetts system of executive selection with the advice and consent of the Senate. ${ }^{47}$ Thus the large states, which saw benefit in purely executive appointment, and the small states, which would have

\footnotetext{
12 See Madison's discussion of the state practice in this regard in Federalist Paper XLVIL.

4s I Max Farrand, The Records of the Federal Convention 20, 21 (1937).

"Id. at 104, 105 .

"EId. at 244 .

10 The discussion of the reconsideration may be found in $i d$. at $124-125$.

${ }^{47}$ For discussion, see 2 FARRAND 41-44.
} 
disproportionate representation in the Senate, each had a portion of their way. ${ }^{48}$

Eventual agreement on Article III involved adjustments throughout the article. As a convenience of discussion, the delegates talked about types of courts, methods of appointment or compensation, and jurisdiction separately. Yet they obviously interact. A man's judgment as to structure may be affected by his concept of jurisdiction. The process of the Constitutional Convention brought a review of historical practice, a compromise of conflicting interests and political necessities, and the creation of a genuinely new type of judicial organization. ${ }^{49}$

\section{III}

\section{The Elements of Federal Jurisdiction}

Jurisdiction posed as many problems as the system itself. For this, too, Randolph and Paterson had answers. The original Randolph plan, which envisioned lower courts, gave jurisdiction which may be summarized as jurisdiction in admiralty, in cases between citizens of different states or foreigners, in cases of federal revenue, in cases of impeachment, and as to "questions which may involve the national peace and harmony." "50 The Paterson plan, assuming appellate jurisdiction only, deleted the diversity jurisdiction in cases of citizens of different states and the "national peace" clause, and added specific reference to treaty cases and federal trade regulation cases. ${ }^{51}$ The Convention tentatively gave jurisdiction in revenue, impeachment, and national peace cases and sent the clause to the Committee on Detail to work out the remainder. 52

The work of that Committee must be seen in relation to the basic general purposes of the Constitution. Those purposes need not be reviewed. Suffice it to say that they included the establishment of a government which could keep

${ }^{48}$ Richards, op. cit. supra note ro, at 23.

40 The establishment of the lower court system was the "transcendent achievement" of the Judiciary Act of i789. Felix Frankfurter and James M. Landis, The Business of the Supreme Court 4 (1927). After the adoption of the Constitution, the judiciary system was given two major examinations, once in connection with proposed Constitutional amendments, and once in the Judiciary Act of 1789 . The history of the Act is told in Warren, New Light on the History of the Federal Judiciary Act of 1789,37 Harv. L. REv. 49 (1923). The principal question to be decided was whether the Congress would take up the option given it to establish lower courts. The Senate attitudes are discussed by Warren at 65-69, and the House attitudes at $123 \mathrm{et} \mathrm{seq}$. The Senate debate is unrecorded, and the House debate, though extensive, offers substantially nothing which would illumine the pre-1 787 conditions leading to Article III other than the basic sentiment that state courts were untrustworthy, particularly in federal question cases. Warren, 124. The other problem was that of amendments to the Constitution itself. The Fifth, Sixth, Seventh, and Eighth Amendments did affect judicial procedures, but Madison's proposal to avoid "vexatious appeals" by requiring a minimum amount for appeals to the United States Supreme Court was lost. See Madison to Pendleton, Sept. I4 and 23, 1789, V Doc. Hist. 205, 2xo; Warren, rx8-rig. In the letter of September 23, Madison reported that others felt that amount was no measure of importance, particularly in constitutional cases. Madison was probably able to accept an opposite point of view because of familiarity with the system of appeals in Virginia and to the Privy Council, described above.

${ }^{50}$ FarRaND, op. cit. stipta, note 43.

EL Ibid.

62 The principal references in the Madison Journal are I Farrand 223, 224, 230, 231, 244, 317; 2 id. at $4 \mathrm{I}-46$, $129 \mathrm{et}$ seq. 
domestic and international peace and which would give full protection to the property and business interests which for various reasons felt much in need of it. It was clearly contemplated that the judges were to be conservative and sound men of property. That most of the delegates at Philadelphia were such men is old knowledge. ${ }^{53}$ They were businessmen and landholders and the lawyers of businessmen and landholders, and they conceived of like men, or indeed of themselves, ${ }^{\text {,4 }}$ as judges under the new system. A good share of the judicial business necessarily would concern property interests, and jurisdictional clauses must be considered accordingly.

For convenience of analysis, the nine federal jurisdictional clauses may be viewed, with some overlapping, from three standpoints: (I) an effective national government; (2) international obligations; and (3) the interests of property.

\section{A. An Effective National Government}

"The judicial Power shall extend to all Cases, in Law and Equity" arising under this Constitution, the Laws of the United States . . . ; to Controversies to which the United States shall be a Party; to Controversies between two or more States."

These are the most important jurisdictional provisions of the Constitution from the standpoint of the basic political maintenance of the government. Without them, or some substitute for them-indeed, without any one of them-it may fairly be doubted whether the government could have survived. So much cannot be said of any other jurisdictional clause, with the possible exception of the treaty provision.

For the purpose of this analysis, the "federal question" and "United States party" clauses may be considered together. The basic weakness of the Confederation had been its inability to make and enforce those demands which are the proper prerogatives of government. Article I gave the new Congress power to make demands. Article III gave a method of enforcing them.

The Confederation had no means of participating in either civil or criminal litigation except on the sufferance of the states. The state courts had to settle federal military accounts; ${ }^{56}$ only the state courts could punish such offenses as treason; ${ }^{67}$

\footnotetext{
${ }^{23}$ The leading analysis from this standpoint is of course CharLes A. BeARd, AN Economic INTERPRETATION OF tHE Constitution, c. 5, 73-15I (i935 ed.).

${ }^{54}$ On September 28, 1789, President Washington appointed delegates Wilson, Blair, and Rutledge to the Supreme Court, delegate Bedford to the district court for Delawarc, and delcgate Read as United States Attorney in Delaware. For Wilson's remarkable application for the Chicf Justiceship ("My aim rises to the important office of Chief Justice of the United States"), see I Charles WarruN, The Supreme Court in United States History 33, 34 (Ig26 ed.).

Eo The inclusion of equity in this fashion is attributed to Connecticut delegate William Samuel Johnson, who had grown attached to that practice in England. George C. Groce, William Samuel. Joknson 165-x67 (1937). It was criticized by the "Federal Farmer" for permitting merger of law and equity poivers in one judge, “. . . for if the law restrain him, he has only to step into his shocs of equity and give what judgment his reason or opinion may dictate." PAUz L. Ford, PAMphLETS on the Constitution 308 (1888).

${ }^{60}$ For discussion of some of these problems, see Sargeant's Essay in Duponcesu, Jurisdiction (1824); I Carson, op. cit. supra, note 24, c. 7; 22 Jour. Cont. Cong. 83, 102 (1914); 23 id. at 773.

${ }^{57} \mathrm{See}$ the numerous treason cases in 1 Dallas. For extensive discussion of the treatment of treason in the Revolution, see Hurst, Treason in the United States, 58 Harv. L. Rev. 226, 246-272 (1944).
} 
only the state courts could punish theft of federal property or frauds on the government. $^{58}$ The Confederation could merely appoint its attorneys to go into state courts. $^{69}$

The sponsors of the Constitution deeply believed that no government could exist without power to enforce its requisitions and its laws. ${ }^{60}$ These clauses reflect that conviction.

As for suits between states, no more need be said. From the earliest times to 1787 , except for the short period of 1775 to $I 78 \mathrm{r}$, there had been a method of settling interstate disputes. The jurisdiction formerly in the Privy Council and then in the arbitral commissions of the Confederation was transferred to the new Supreme Court. ${ }^{01}$

\section{B. International Affairs}

“. . to all Cases ... arising under ... Treaties . . . ; to all cases affecting Ambassadors, other public Ministers and Consuls; to all Cases of Admiralty and maritime Jurisdiction."

The Confederation had found itself powerless to conduct the international affairs of the states. ${ }^{62}$ It could make agreements, but it could not enforce them. It could not even extend to foreign nations an assurance of protection of their representatives in America. The treaty with Great Britain, particularly in respect to debts payable to British merchants or creditors, was being ignored; ${ }^{63}$ and the case of de Longchamps had great potential of national embarrassment.

The Chevalier de Longchamps had a standing grudge against Francis Barbe Marbois, French consul-general at Philadelphia. Epithets at the consulate were followed by blows on the street, and though the French official had the best of the battle, further punishment for de Longchamps was in order. He was prosecuted in Pennsylvania courts and heavily-almost preposterously heavily-sentenced, doubtless more as a menace to relations with France than as a threat to the peace. ${ }^{64}$

\footnotetext{
${ }^{68}$ See for examples Respublica v. Sweers, I Dall. 4I (U. S. 1779) (deputy Commissary-General charged with fraud in connection with army stores); Respublica v. Powell, r Dall. 47 (U. S. 1780) (army baker charged with short weighting).

${ }^{\circ 0}$ As in the Sweers case, cited supra, note 58.

${ }^{10}$ Citations would be merely cumulative. The basic social evil to be remedied, as Washington expressed it in a gloomy letter to Madison before the Convention, March 31, $7_{787}$, was put thus: "I confess, however, that my opinion of public virtue is so far changed that I have my doubts, whether any system without the means of Coercion in the Sovereign will enforce due obedience to the Ordinances of a general Government without which everything else fails." IV Doc. HIST. roz.

o1 The threat of interstate war and past devices are considered by Hamilton in Federalist Paper LXXX.

02 The judiciary is discussed from the standpoint of maintenance of international peace in Federalist Paper IXXX.

${ }^{63}$ Wilson discussed the ill consequences of the non-enforcement of the British treaty in the Pennsylvania convention. 2 ElliotT $489,490$.

o4 Respublica v. De Longchamps, I Dall. III (U. S. I784). The defendant was heavily fined, sentenced to imprisonment for two years, and put on bond in addition. The discussion at II5, II6 shows that France wanted an even more severe penalty. The case is suggestive of the manner in which the United States has on occasion made a small nation eat crow for failing to give adequate protection to an official. Cf. the Iranian incident, is AM. J. INT'z L. 768 (1924).
} 
None the less, suppose Pennsylvania had not prosecuted. The foreign relations of every state were at the mercy of the one state in which an incident occurred. The Convention was convinced that if foreign officials were either to seek justice at law or be subjected to its penalties, it should be at the hand of the national government. The Supreme Court proceeded immediately to enforce the British treaty, ${ }^{05}$ and the lower courts heard numerous cases like that of de Longchamps. ${ }^{66}$

The admiralty and maritime jurisdiction had a double purpose, both international and economic. Admiralty cases might involve the relations of the United States with foreign countries, and the same basic conviction which gave national jurisdiction in respect to treaties and ambassadors required it here. The lines between piracy and privateering were thin, and yet the difference might affect war and peace; and the seizure of the two Spanish ships during the Revolution taught a strong lesson. There were few to contest the argument of James Wilson that admiralty jurisdiction must be wholly national since "it related to cases not within the jurisdiction of particular states, and to a scene in which controversies with foreigners would be most likely to happen." ${ }^{n t}$

\section{Property and Trade}

"... to all Cases ... arising under this Constitution, the laws of the United States and Treaties made, or which shall be made...; between a State and Citizens of another State; between citizens of different States; between citizens of the same State claiming Lands under Grants of different States, and between a State, or the Citizens thereof, and foreign States, Citizens, or Subjects."

The Constitution, said Hamilton while its ratification was pending, had "the good will of the commercial interest throughout the states which will give all its efforts to the establishment of a government capable of regulating, protecting, and extending the commerce of the Union ... the good will of most men of property in the several states who wish a government of the Union able to protect them against domestic violence and the depredations which the democratic spirit is apt to make on property." "Ar . Article III was a part of a unified program calculated to enlist the support of "most men of property."

For this purpose the most obvious clause was that giving jurisdiction in federalquestion cases. The three central prohibitions of the Constitution from a standpoint of contemporary economic interest were the prohibitions on state impairment of

o6 Ware v. Hylton, 3 Dall. 199 (U. S. 1796).

${ }^{\circ 0}$ United States v. Liddle, 2 Wash. 205 (C. C. Pa. 1808); United States v. Hand, id. at 435 (1810). This is not to say that the foreign-minister clause was essential to the taking of jurisdiction in case like that of de Longchamps, since these would become federal questions without that clause under Art. $\mathrm{I}, \$ 8, \mathrm{cl}$. Io (offenses against the law of nations). This is none the less suggestive of the general kind of trouble the delegates had in mind. A typical example of a sort of problem in foreign relations which belongs in federal court, in this case in admiralty, is The Schooner Exchange v. M'Faddon, 7 Cranch 116 (U. S. 18I2).

ot I FaRRand 124.

${ }^{68}$ IV Doc. HIst. 288 (1787). 
contracts, state currency, and state tariffs. ${ }^{69}$ If a state should violate these prohibitions the courts were to invalidate the violating statutes. ${ }^{70}$ In addition, Congress could regulate commerce, and impinging state regulations could be invalidated by jurisdiction granted under the phrase "constitution or laws."

The treaty jurisdiction was an important element of the Constitution viewed either from the standpoint of international affairs or of economic matters. The basic power to make treaties gave rise to fears, notably in Kentucky, that treaties inimical to regional economic interests would be made and enforced. ${ }^{71}$ In addition, the phrase giving jurisdiction in cases arising from "Treaties made, or which shall be made" torpedoed the hopes of those who desired to avoid the payment of British debts, secured under the Treaty of $1783^{72}$ Madison said, "The articles relating to Treaties-to paper money, and to contracts, created more enemies than all the errors in the System positive and negative put together."73

The remaining clauses can be viewed from many standpoints, and this sketch will deal with three: (I) What was the relation of real property interests to the judicial article? (2) What was the basic purpose of the diversity jurisdiction? and (3) Measured by the use actually made of the federal courts in the period immediately after their creation, what conclusions, if any, can be drawn about the purposes of Article III? For such illumination as it may shed on the other two questions, the third will be considered first.

\section{The federal courts, 1790-1815}

A statistical analysis of the actual operations of the federal courts, even in their infancy, is far from being a fool-proof means of determining their purpose. The Founding Fathers may have made mistakes of judgment about what would prove important, and the growth of the country itself materially affected the business of the courts.

None the less, performance is at least some measure of purpose. It permits the statement of some working hypotheses which, tested against others, may indicate fruitful lines for analysis. For this limited purpose, the following data is offered.

Table I gives a jurisdictional and functional analysis for 434 cases reported in the Supreme Court in the years I790-1815. The sources of the cases and the problems and weaknesses of classification are discussed in the appended note.

${ }^{\circ}$ These three basic prohibitions are discussed together by Madison in Federalist Paper XLIV.

${ }^{70}$ Discussed by Hamilton in Federalist Paper LXXVII, in which he analyzes the judiciary as "an essential safeguard against the effects of occasional ill humors in the society."

${ }^{71}$ The argument skillfully made to the delegates from Kentucky at the Virginia convention was that the southern states would never willingly give up the navigation of the Mississippi to the Spanish, while the northern states were indifferent to it. Under the Confederation, southern votes could block such a move, but under the Constitution the southern states might be outvoted. See, for a few of many examples of this discussion, the remarks of Henry at 3 ElLrotr 151, 152; Lee, id. at r82; Grayson, id. at 501,505 .

72 I AlBert J. Beveridge, Life of John Marshall 44I, 444 (19i6).

${ }^{73}$ Madison to Jefferson, October 17, 1788, V Doc. Hist. $85,86$. 
TABLE I

Business of the Supreme Court, I790-18 $15^{\text {T4 }}$

\begin{tabular}{|c|c|c|c|c|}
\hline JURISDICTION & $1790-1800$ & $1801-1810$ & $1811-1815$ & Total \\
\hline \multirow{2}{*}{ 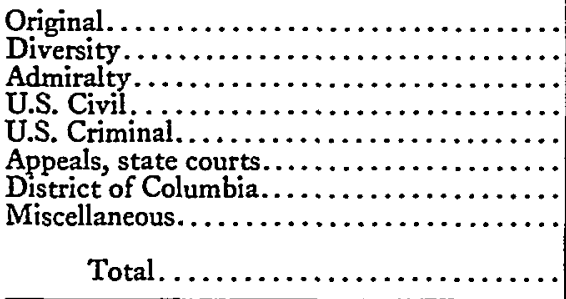 } & $\begin{array}{r}8 \\
18 \\
16 \\
3 \\
1 \\
3 \\
3 \\
0 \\
7\end{array}$ & $\begin{array}{r}1 \\
71 \\
22 \\
17 \\
3 \\
7 \\
79 \\
21\end{array}$ & $\begin{array}{r}0 \\
46 \\
46 \\
12 \\
2 \\
7 \\
41 \\
3\end{array}$ & $\begin{array}{r}9 \\
135 \\
84 \\
32 \\
6 \\
17 \\
120 \\
31\end{array}$ \\
\hline & .. & .. & $\ldots$ & 434 \\
\hline \multirow[b]{2}{*}{ 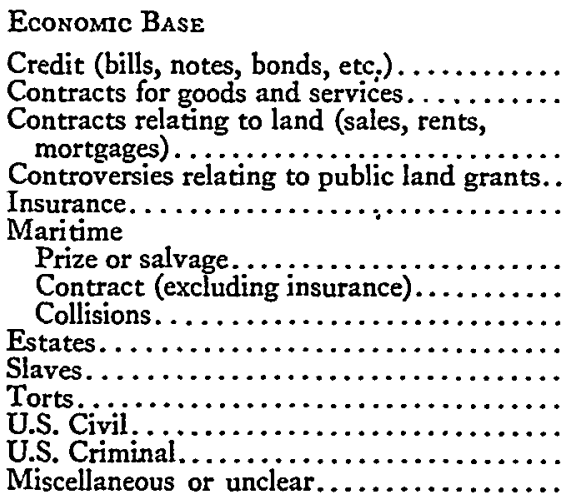 } & & & & \\
\hline & $\begin{array}{r}9 \\
2 \\
4 \\
4 \\
0 \\
15 \\
1 \\
0 \\
1 \\
0 \\
0 \\
3 \\
1 \\
16\end{array}$ & $\begin{array}{r}30 \\
13 \\
23 \\
12 \\
23 \\
\\
26 \\
3 \\
0 \\
10 \\
6 \\
1 \\
21 \\
5 \\
48\end{array}$ & $\begin{array}{r}15 \\
6 \\
26 \\
9 \\
16 \\
\\
47 \\
2 \\
0 \\
4 \\
2 \\
0 \\
15 \\
2 \\
13\end{array}$ & $\begin{array}{r}54 \\
21 \\
\\
53 \\
25 \\
39 \\
\\
88 \\
6 \\
0 \\
15 \\
8 \\
1 \\
39 \\
8 \\
77\end{array}$ \\
\hline Total............ & .. & $\ldots$ & . & 434 \\
\hline
\end{tabular}

Table 2 gives a similar analysis of 647 cases reported in the federal circuit courts in the same period. ${ }^{75}$

On the basis of these tables and the underlying study, certain conclusions may be stated:

I. Quantity of cases is not in itself a highly significant measure of constitutional purpose. Else one would be forced to believe that a primary purpose in creating

74 This table omits those cases reported so briefly that, without the record, not even an intelligent guess can be made as to either jurisdiction or interest. The miscellaneous category includes the few patent cases. The seventy-seven "miscellaneous or unclear" cases in the economic table include sixty-eight cases in which the report is too short to permit a guess at the interest.

Credit cases have been put as a separate category from sales, contracts, and mortgages for two reasons: (I) many of the reports reveal that the suit was on a note, but not what the note secured; (2) in the early economy, with shortage of money and in the absence of corporate stocks and bonds, notes were used as a medium of exchange or for speculation. Hence they represent a separable interest. For a good example of a wandering note, see Steinmetz v. Currie, I Dall. 269 (Pa. 1788). The economic table attempts to reach the fundamental interest without regard to form. For example, there are more cases involving government civil interests or maritime interests than actually arise jurisdictionally in that form.

${ }^{75}$ The comments in the preceding note are applicable here. These cases were taken from the following reports: 2-4 Dallas; Brunner; Wallace Sr.; I-3 Washington; I Brockenborough; I Peters (circuit); I Paine; I-2 Gallison. 
TABLE 2

Business of the Federal Circuit Courts, I790-1815

\begin{tabular}{|c|c|c|c|c|}
\hline JURISDICTION & $1790-1800$ & $1801-1810$ & $1811-1815$ & Total \\
\hline \multirow{2}{*}{ 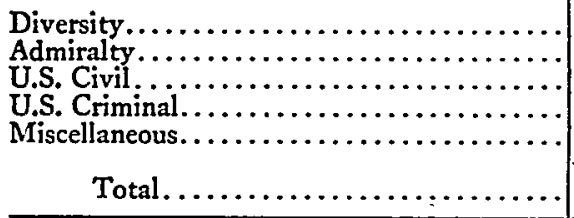 } & $\begin{array}{r}23 \\
1 \\
2 \\
14 \\
3\end{array}$ & $\begin{array}{r}212 \\
23 \\
10 \\
23 \\
19\end{array}$ & $\begin{array}{r}133 \\
104 \\
37 \\
28 \\
15\end{array}$ & $\begin{array}{r}368 \\
128 \\
49 \\
65 \\
37\end{array}$ \\
\hline & .. &.. & . & $6 \pm 7$ \\
\hline \multirow[b]{2}{*}{ 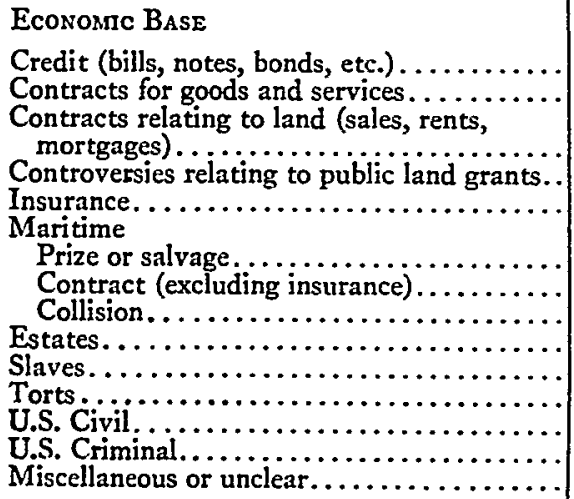 } & & & & \\
\hline & $\begin{array}{r}7 \\
1 \\
7 \\
1 \\
2 \\
2 \\
2 \\
0 \\
0 \\
0 \\
0 \\
2 \\
2 \\
14 \\
5\end{array}$ & $\begin{array}{r}45 \\
29 \\
43 \\
7 \\
50 \\
17 \\
22 \\
1 \\
3 \\
2 \\
4 \\
12 \\
23 \\
29\end{array}$ & $\begin{array}{r}23 \\
14 \\
46 \\
1 \\
16 \\
87 \\
21 \\
0 \\
11 \\
2 \\
4 \\
38 \\
28 \\
26\end{array}$ & $\begin{array}{r}75 \\
44 \\
96 \\
9 \\
68 \\
\\
106 \\
43 \\
1 \\
14 \\
4 \\
10 \\
52 \\
65 \\
60\end{array}$ \\
\hline Total. & .. & . & .. & 647 \\
\hline
\end{tabular}

the Supreme Court was to furnish a tribunal for the settlement of cases arising in the District of Columbia.

2. There was, quantitatively, very little immediate need for a Supreme Court in 1787 or for some years thereafter.

3. Many of the large number of District of Columbia cases could have been diversity cases had they arisen elsewhere. Such factors as physical distance probably discouraged the institution of cases in other federal trial courts and certainly discouraged appeals from other federal courts.

4. The number of serious and important federal questions actually considered in the Supreme Court was minute. United States civil and criminal cases were few and, for the most part, trifling. The number of appeals from state courts which could raise serious federal questions was only seventeen in twenty-five years, and while important public questions arose from other sources, they were rare. ${ }^{76}$

5. At the beginning of the period, the principal economic groups involved in litigation, quantitatively at least, were the shipping industry, the holders of bills and notes, and those who dealt in land. However, a new industry, insurance, was on the horizon, and by 1815 furnished an important part of federal work. The

"For examples, Marbury v. Madison, I Cranch x37 (U. S. I803), original; Fletcher v. Peck, 6 Cranch 87 (U. S. I8ro), diversity. 
shipping problems were primarily prize and salvage, although before the end of the period contract cases were appearing; and most of the insurance cases were ship insurance problems. Throughout the period, however, and particularly at the beginning, the international aspects of admiralty were the most important in litigation. Tort cases in diversity were almost nonexistent, as were problems of banks or corporations.

6. In the lower courts the business originated predominantly in diversity and admiralty. Excluding the District of Columbia cases, the principal differences between the two levels of courts in this period were that the lower courts had a somewhat higher proportion of Government business and had received more maritime contract problems other than insurance.

7. The whole federal judicial system from 1790 to 1815 gave almost its entire attention to the settlement of the simplest types of commercial and property disputes. It was, in addition, enforcing some federal statutes, particularly those relating to the shipping embargo and the War of $x 8 \mathrm{r2}$. Over half of the small business of the federal courts could have been handled substantially as well in state tribunals.

\section{Land titles}

Assuming that historians need no longer re-contest the ground which Dr. Charles A. Beard has already won, we may start with a fixed assumption that economic events have a great deal to do with political and constitutional developments. That being so, the relation of land speculation to the Constitution and to the Judiciary Article presents a puzzling problem on which only the most tentative observations can be made at the present stage of research. Yet despite lack of tangible evidence, it would surpass belief that this portion of the Constitution could have been written without consideration of land speculating interests.

In 1787 there were fortunes to be made in buying land cheaply from state or federal governments, bringing in settlers from the East or from Europe, and selling at a good profit. Prior to the Revolution there were ten principal land companies in the colonies, the two best known in our own age being the Ohio Company of 1748 , in which George Washington was an active participant, and the Transylvania project, remembered principally because its promoter, Richard Henderson, bought 20,000 acres in Kentucky from the Cherokees at three cents an acre and sent Daniel Boone on his way to legend by making him the explorer of the area. ${ }^{77}$

These concerns knew how to manipulate governments. Frequently they had to. ${ }^{78}$

${ }^{77}$ There has been extensive publication on the land companies. However, a number of writers have become preoccupied with the scandals, and obscured the facts. The leading general work on land policy is Benjamin H. Hibbakd, a History of the Public Land Policies (1924), and a good specialized work on this period which analyzes separately each of the ten companies referred to is Sunw Ltverasore, EarLy AMerican Land Companies 74-132 (1938). Land sales under the Confederation are discussed sedately in Payson J. Treat, The National Land System, 1785-1820 4T-66 (1910), and considerably less sedately in Aaron M. Sakolski, The Grest American Land Bubble I-123 (1932); Alfred M. Chandler, Land Titze Origins 72 et seq. (1945).

${ }^{78}$ It is principally to the Ohio Company of Associates, which desired to obtain and sell land in Ohio, that credit should go for the Northwest Ordinance of 1787 , which established a government for 
Administrative officials were cut in when necessary to win official approval. ${ }^{79}$ These were big operations, carried on by men of imagination and power. After the Revolution it was no longer necessary for the speculators to deal with a distant England, and they turned their whole attention to the state, Confederation, and national governments.

Within a few years of the Revolution ten more great land companies were formed. ${ }^{80}$ Among those interested were many of the principal figures of the Constitutional Convention. The largest of all was Robert Morris of Pennsylvania, who in r79I owned, among other land interests, 5,300,000 acres in western New York and who may well have been the biggest real estate speculator of all time. ${ }^{81}$ Both Morris and his lawyer, James Wilson, were strong Federalist delegates to the Convention from Philadelphia, and Wilson, one of Washington's first appointees to the Supreme Court, was active in the formulation of the judicial portions of the Constitution. Other delegates active in land speculation were Washington and Mason of Virginia, Blount of South Carolina, Carroll of Maryland, Dayton of New Jersey, Fitzsimons and Franklin of Pennsylvania, and at least five others. ${ }^{82}$

Not only were the speculators, or persons interested in speculation, participants in the Convention, but they were in various other ways close to Convention members. One of Washington's principal non-convention advisers, for example, and his first Secretary of War, was General Henry Knox of New York, who in r79I was one of a group which bought two million acres in Maine at ten cents an acre. ${ }^{83}$ The Reverend Manasseh Cutler, preacher, botanist, and businessman, was at the very moment of the Philadelphia Convention engaged before the Confederation Congress in New York in wangling a $1 \frac{1}{2} 2$-million-acre grant for his Ohio Company of Associates. Cutler was compelled to take $3 \frac{1}{2}$ million acres more than he wanted, to be divided among persons of influence, in order to get his own grant of $\mathrm{I}^{1 / 2}$ million. ${ }^{84}$ While working on his great project in New York he came to Philadelphia and had an extended and congenial visit, including an outing in the country, with Convention delegates Madison, Hamilton, Mason, and Rutledge, among others. ${ }^{85} \mathrm{He}$ eventually went back to Massachusetts and supported ratification there.

that area. For one of many discussions, see Charles A. Beard, The Rise of Amertcan Civilization 510-513 (I935 ed.). The problem is briefly mentioned in Fred Rodell, FiftY-Five MEN I8 (1936).

${ }^{70} \mathrm{See}$, for example, the participation of Lord Dunmore, Governor of Virginia, in the affairs of the Indiana Company, Livermore, op. cit. supra, note 77 , at 108 .

${ }^{80}$ Each is described in id. at $133-214$.

${ }^{81}$ Ellis P. Oberholmzer, Robert Morris, Patriot and Finsucier (I903). On the New York speculations, see SAKorskr, op. cit. sttpra, note 77, c. 3 .

${ }^{82}$ List taken from Charles A. Beard, Economic Interpretation of the Constitution, c. 5, and particularly 15I. (1935 ed.)

${ }^{83}$ Liversore, op. cit. supra, note 77, at $174-177$. For an extended statement by Knox to Washington of the former's pre-Convention views, see letter, Jan. 4, 1787 , IV Doc. Hist. 58.

${ }^{84}$ For a crisp account of the incident see Charles A. Beard, The Rise of American Givilization (1935 ed.). For a leisurely account, the Cutler Diary is fascinating reading. I LifE, JourNals AND Correspondence of Rev. Manasseh Cuther, Ll.D. xi9-373 (W. Parker and Julia P. Cutler, eds., i888).

${ }^{85}$ Cutler Diary, supra, note 84 , July 14,1787 , at $271-279$. 
Several of the jurisdictional clauses were of actual practical significance to large landholders. The most obvious relevant clause was that granting jurisdiction in controversies "between Citizens of the same state claiming lands under grants of different states," a clause that at least possibly could affect every eastern speculator who held land in Ohio, Kentucky, Tennessee, or Maine-areas soon likely to become new states and to have some notions of their own as to who should own the lands within their borders. ${ }^{86}$

However, the diversity and treaty clauses were the jurisdictional clauses most immediately affecting large landed interests. The wording of the treaty clause determined who should own several hundred thousand acres in the Northern Neck of Virginia; and the diversity clause permitted speculators holding land under state grants to litigate questions of title in federal courts which, it must be remembered, were to be part of a government friendly to "men of property."

The implications of the Constitution for land-holding interests received comparatively little recorded public discussion in the course of ratification of the Constitution. A local appeal to New Hampshire based on the "grants of different states" clause is a rare instance of public attention. ${ }^{87}$ In Virginia, however, the ratifying convention did discuss the clauses in relation to the two specific land interests of that state, the Fairfax estate and the Indiana Company. A word must be said as to each.

Lord Fairfax, Washington's friend and neighbor, held title before the Revolution to some 300,000 acres in that northeastern sector of Virginia south of the Potomac known as the Northern Neck. Virginia confiscated interests in these with other royalist lands and parceled some of them out again. Among others, George Mason had a substantial interest in them after the re-shuffling. Mason was one of Virginia's wealthiest men and had been a delegate at Philadelphia but refused to sign the Constitution. With Patrick Henry, he led the opposition in Virginia. ${ }^{88}$ The treaty of peace in 1783 promised a return of the confiscated property. The one chance of the Fairfax heirs was that a federal judiciary might enforce that treaty.

Whether the Indiana Company took an active part in the Virginia convention has

${ }^{\text {so }}$ This clause seems to have originated in the efforts of Vermont to sccure independence from both New Hampshire and New York. Sharp controversies followed Vermont's "declaration of independence" from its neighbors on January 15,1777 , and in 1779 , as a result of border controversics, Congress requested the states involved to permit it to resolve disputes arising out of land grants from the different states. For details see 13 r U. S., App. I-liii.

${ }^{87}$ Agrippa (James Winthrop), in Paul L. Ford, Essays on rhe Construturion 75 (1892).

${ }^{88}$ See Helen D. Hill, George Mason (1938), passim, and on his opposition to the Constitution, 213-238. A rather remarkable theory of the reason for the divergence of the Virginia political leaders on the Constitution is offered in an earnestly anti-Constitutional study, Grigsby, The History of the Virginia Federal Convention, 9 VA. Hist. Soc. Collec. 42, n. 48 (1890): Washington, Pendlcton, Wythe, and Madison were the strongest supporters of the Constitution. If one looks to unconscious guiding factors "it may be said that they were all men of wealth, or held office by a life tenure, and that, though married, neither of them ever had a child. In the same spirit it may be mentioned that Mason and Henry were men of large families, and that hundreds now living look back to 'Gunston Hall' or 'Red Hill.' In the case of Henry, the cradle began to rock in his house in his eighteenth year, and was rocking at his death in his sixty-third." 
not been traced, but it had probably the largest immediate stake in the adoption of the Constitution of any business enterprise existing in 1787 . In 1768 , after the most elaborate negotiations, the Indiana Company "bought" from the Indians of the Six Nations $3 \frac{1}{2}$ million acres of land in what is now West Virginia. Between 1776 and 1779 the issue of title was fought out with Virginia. Mason led the opposition and Edmund Randolph represented the company before the Virginia assembly in those years. Mason prevailed and the company seemed lost. Meanwhile many Virginians settled in the claimed area. ${ }^{80}$

Mason's attack on the judiciary sections at the Virginia convention was specific and candid. He could not vote for the Constitution so long as the judiciary clause stood as it was. He reminded his listeners that his own pecuniary interests demanded the non-enforcement of the Treaty of 1783 . If it were ever enforced, he conceded, his own interests in the Fairfax land would be adversely affected. ${ }^{30}$ In addition, he argued, the Constitution would give the Indiana Company an opportunity to reassert its claim before the federal courts, and therefore the residents of the area involved should oppose the Constitution if they did not want to pay tithes to the Indiana Company. ${ }^{91}$ He proposed an amendment that the federal judicial power should apply only to such causes of action arising after the adoption of the Constitution. ${ }^{2}$

Marshall and Randolph, among others, answered that Mason's fears were groundless because the federal judiciary would respect the Virginia determination on the Indiana Company; and that if the Fairfax heirs were entitled to the land, they should have it. ${ }^{93}$

Mason's predictions were shrewd. Within a few years Marshall became counsel for the Fairfax interests, and eventually, financed by Robert Morris, a Marshall syndicate bought the property. ${ }^{94}$ The Supreme Court upheld the Fairfax-Marshall title. ${ }^{95}$ The Indiana Company did sue Virginia in the United States Supreme Court, which took jurisdiction. ${ }^{98}$ Thereupon Virginia and Georgia, concerned because of

${ }^{80}$ For an extended account of these affairs see George E. Lewis, The Indiana Company, I7631798 (194I). Failing in Virginia, the company appealed to the Confederation Congress, hiring Thomas Paine as its propagandist for 300 shares. Paine wrote a pamphlet in support of the company entitled "Public Good." These latter incidents are described in Merrill Jensen, The Articles of ConfederaTHON 121 et seq., 218, 233 (1940).

90 "I am personally endangered as an inhabitant of the Northern Neck. The people of that part will be obliged, by the operation of this power, to pay the quitrent of their lands. Whatever other gentlemen may think, I consider this as a most serious alarm." 3 EzLIotr $\mathbf{5 2 8 .}$

${ }^{82}$ Id. at 529 .

o2 Id. at $53^{\circ}$.

${ }^{93} \mathrm{Id}$. at 559, 574. Beveridge notes that Marshall himself "was then personally interested in the Fairfax title," and adds, "His own and his father's lands in Fauquier County were derived through the Fairfax title." I Beveridge, op. cit. stipra, note 72, at 448. Randolph, formerly counsel for the Indiana Company, assured the delegates that in the future "the remedy will not be sought against the settlers, but [against] the state of Virgina." 3 ELIIotT 574.

"The transaction is described in 2 Beveridge, op. cit. stipra, note 72, at r99-21 I.

${ }^{95}$ Fairfax's Devisee v. Hunter's Lessee, 7 Cranch 603 (U. S. I813); Martin v. Hunter's Lessee, I Wheat. 304 (U. S. 1816 ).

${ }^{\circ 0}$ Grayson v. Virginia, 3 Dall. 320 (U. S. 1796). 
Chisholm v. Georgia, allied in writing the Eleventh Amendment and sovereign immunity into the Constitution, and the Indiana Company's claims were finally dismissed. ${ }^{97}$

As Tables I and 2 show, there is record of nine cases in the lower court reports and twenty-five in the Supreme Court involving interests in public lands between ${ } 790$ and $\mathrm{r} \mathrm{r}_{5}$. Most of these were small affairs, quarrels over soldiers' bounty land, for example. But some were important. The Fairfax estate case, arising as a federal question based on the treaty clause, has been mentioned. Fletcher v. Peck, ${ }^{08}$ a feigned case brought in diversity to settle the title to the Yazoo lands in Georgia, is well known. Another was Fitzsimons v. Ogden, ${ }^{09}$ in which, in an extremely complicated situation, Gouverneur Morris, a delegate at Philadelphia, emerged triumphant with the stupendous remnant of Robert Morris' fallen estate. The case arose in diversity and involved no federal question. The Court found that G. Morris had been "unkind" but not fraudulent to the R. Morris interests.

Other land company cases were Huidekoper's Lessee v. Douglass, ${ }^{100}$ a case which may also have been carefully arranged to put it into diversity. The issue was whether the Holland Company, purchaser of hundreds of thousands of acres from Pennsylvania, should lose title for failure to give full compliance with its contract. Marshall's language in deciding this non-federal question is revealing of the Court's essential spirit of friendliness to the land companies. ${ }^{101}$ In Pendleton and Webb v. Wambersie, ${ }^{102}$ the Court in kindly fashion lent federal jurisdiction to untangling the affairs of a land company which had stretched its shoe string beyond the breaking point, and in Town of Pawlet v. Clark ${ }^{103}$ it gave full-and logical-scope to the clause concerning grants from two states.

This much of a hypothesis is offered for further exploration: A large commercial interest in the country and in the Convention in 1787 was that of the existing or immediately impending land companies. The judiciary article was specifically discussed in terms of land speculations at least in Virginia. The Supreme Court aided virtually every land speculator who came before it from 1790 to $1815,{ }^{104}$ and the federal jurisdictional clauses and particularly the diversity clause gave most material assistance for that purpose. In all probability the drafters at Philadelphia, or at least some of them, had some such benefits in mind as one of the factors influencing their drafting of Article III.

\section{The diversity jurisdiction}

The most obvious explanation of the two clauses in Article III giving jurisdiction

${ }^{87}$ Hollingsworth v. Virginia, 3 Dall. 378 (U. S. 1798 ). For an analysis of this litigation, and the steps taken by Virginia, see Lewis, op. cit. stupra, note 89, at 277-29r.

${ }^{88} 6$ Cranch 87 (U. S. $x 810$ ).

${ }^{100} 3$ Cranch I (U. S. 1805 ).

1024 Cranch 73 (U. S. 1807).

7 Cranch 2 (U. S. 1812 ).

${ }^{202}$ Id. at 70-7r.

${ }^{103} 9$ Cranch 292 (U. S. 1815 ).

304 Except for George Mason. Had he lived, his cup of misery would have run over when he lost title to 8300 acres of land in Kentucky on the ground of improprieties in his survey.' Wilson v. Richard Mason, devisee of George Mason, I Cranch 45 (U. S. I801). 
in private cases in which one party is not a citizen of the state in which the suit is brought is the explanation most often given: the drafters of the Constitution thought either that justice or the important appearance of justice would be denied if such cases were left to state decision. So Marshall early declared. ${ }^{105}$

But the brilliant article by Mr. Friendly in $1928^{106}$ and the forceful statement by then Professor Frankfurter, ${ }^{107}$ based in part on the Friendly researches, casts grave doubts on the accuracy of the obvious. Their publications and the firm response of Professor Yntema and Mr. Jaffin leave the reason for diversity a matter of sharp disagreement. $^{108}$

The Friendly-Frankfurter position in rough summary may be put thus: An examination of available records, particularly decisions of state appellate courts before 1787 , does not show any record of bias of state courts in favor of their own. The records and debates at Philadelphia and in the states show no evidence of a conviction that such bias existed, for not one speaker made a clear statement to that effect. Those debates do show that support for diversity jurisdiction, even among its friends such as Wilson and Marshall, was "tepid," and that it was based essentially not on fears of regional bias but on fears of class bias: e.g., that in a vague but real sense the drafters of Article III thought that the federal courts would counterbalance the spirit of paper money and debt relief in state legislatures. ${ }^{109}$ Actual local hostility, says Friendly, "had only a speculative existence in $1789 . " 110$

To this Yntema and Jaffin say, essentially, "Unproved." There are too few recorded cases to measure actual hostility, they say; ${ }^{111}$ and the absence of discussion in 1787 and 1788 may mean merely that it was impolitic and unnecessary to attack state judges. ${ }^{112}$ From the records they extract phrases which indicate there was actual hostility. ${ }^{113}$ However, the essential bulwark of this position-which, it must be emphasized, they do not contend they have proved-is that it is incredible

${ }^{105}$ The Bank of the United States v. Deveaux, 5 Cranch 6r, 87 (U. S. I809). For fuller statement of this view, see Joseph Story, Commentaries on the Constitumon 629 et seq. (1833).

${ }^{100}$ Friendly, The Historic Basis of Diversity Iurisdiction, 4I Harv. L. Rev. 483 (I928).

${ }^{107}$ Frankfurter, Distribution of Judicial Power Between United States and State Courts, 13 CorN. L. Q. 499 ( 1928 ).

${ }_{108}$ Yntema and Jaffin, Preliminary Analysis of Concurrent Jurisdiction, 79 U. of PA. L. Rev. 869 (x93I).

100 "The available records disclose no particular grievance against state tribunals for discrimination against litigants from without. The real fear was of state legislatures, not of state courts." Frankfurter, stipra note 107 , at 520 .

${ }^{220}$ Friendly, supra note xo6, at 510 .

123 Yntema, supra note 108 , at 876 , n. 13.

${ }^{122}$ Id. at 875 , n. 13 . If, for example, the hypothesis advanced earlier of relation of land interests to the judiciary is sound, it is easy to believe that in 1787 as at some other times politicians were not talking about all the subjects they were thinking about. Madison wrote Hamilton as follows during the Virginia consideration of the judiciary: "The attacks on it [the judiciary] have apparently made less impression than was feared. But they may be secretly felt by particular interests that would not make the acknowledgment, and wd. chuse to ground their vote agst. the Constitution on other motives." Letter, June 22, I788, IV Doc. Hist. 745.

${ }^{123}$ Yntema, supra note 108, at 876 , n. 13. 
that in the narrow, provincial, petty spirit of inter-colonial relations, there should not have been local bias in the administration of justice. ${ }^{114}$

Both positions carry persuasion despite apparent conflict. On the one hand it is incredible that the colonies should have administered justice with complete fairness to each other. On the other hand, it is true that there was very little concrete evidence of hostility in specific lawsuits. The evidence does show that in 1787 bias in interstate lawsuits was more an anticipated than an existing evil.

The explanation of the paradox of inevitable bias and yet no bias lies in the character of pre-r 787 litigation. In the first place, there is some record of actual bias, intra-empire if not interstate. There can be no doubt, for example, of direct bias in the administration of justice against British creditors in Virginia. There in 1770 the jurisdiction of the Court of Hustings at Williamsburg, in which creditors had previously proceeded, was sharply constricted for the purpose of putting creditors at the mercy of county courts which could be relied upon to make debt collection difficult. ${ }^{115}$ The purpose was contemporaneously so understood. ${ }^{116}$ Similarly at least two of the state judgments in admiralty cases between 1777 and 1786 were probably products of bias in favor of state interests. ${ }^{117}$

And yet the problem was not an acute one in 1787 for reasons going to the nature of the domestic economy of the colonies and states. There was too little significant interstate business litigation to give room for serious actual abrasion.

Table 3 analyzes 554 reported cases in seven colonies and states from 1658 to 1787. These are substantially all available reported cases. ${ }^{118}$ The table cannot be accurate, for in too many cases one can at best make a good guess as to whether a case was of local or diverse origin. Many doubts were decided in favor of listing the case in diversity.

These data and the underlying cases indicate that the volume and certainly the proportion of interstate commercial litigation were extremely low. This is indicated by several factors: (I) A higher proportion of diversity than of local cases must have been appealed or come into the reports, because such cases would have to be of at

\footnotetext{
124 The conviction that "the theory of no local prejudice is presumptively improbable" is stated and documented in Yntema, stepra note 108, at 876, n. 13 .

2108 Henning (Va. Stat.) 40r, 402.

${ }^{110}$ John Tazewell, Williamsburg attorney, wrote his client, John Norton, English merchant, on July 12, 1770: "If this Law is not disallowed, Creditors for the recovery of their Debts must either bring their Suits in the General or County Courts where Years must elapse before an unjust or unwilling debtor can be brought to Justice." Quoted in George L. Chumbley, Colonial Justice in Viroinia 148,150 (1938), as part of a general discussion of this subject. English agents charged the purpose of the change of jurisdiction was to make debt collection difficult, and Chumbley concludes, "An unbiased study of the matter indicates that they were right in their conclusions." Id. at 148 .

${ }^{112}$ For details see Penhallow v. Doane, 3 Dall. 54 (U. S. 1795), and United States v. Judge Peters, 5 Cranch II5 (U. S. I809).

${ }^{128}$ These cases are taken from Kirby and the Acorn Club Kirby Supplement of I933 (Conn.); I Harris \& McHenry (Md.); Quincy (Mass.); I Martin (N. C.); I and 2 Dallas (Pa.); I Bay (S. C.); Jefferson and 4 Call (Va.). It cannot be too strongly emphasized that these records are in such form that the listings are very nearly guesswork. A large number of cases on which not even a gucss could be made are omitted.
} 
TABLE 3

Distribution of Local and Diversity Cases, Colonial and StATE Courts, I658-i 787 (Scattered Reports)

\begin{tabular}{|c|c|c|}
\hline State & LOCAI ORIGIN & Diverse Origin \\
\hline 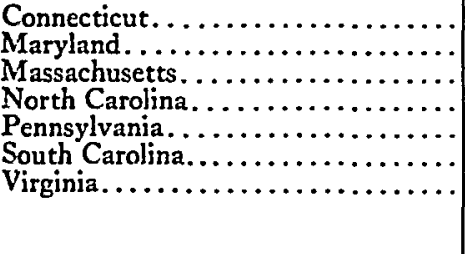 & $\begin{array}{r}192 \\
136 \\
67 \\
4 \\
74 \\
28 \\
38 \\
\frac{}{539}\end{array}$ & $\begin{array}{r}26 \\
6 \\
2 \\
1 \\
13 \\
6 \\
\frac{1}{55} \quad 9.26 \%\end{array}$ \\
\hline
\end{tabular}

least some importance to be worth bringing in the first place. It is probably safe to assume that if from these sources we find 9.26 per cent of the cases in diversity, the actual proportion was far lower. (2) Many of these cases were not interstate cases, but English-state cases. In the six Maryland diversity cases, for example, four probably involved English interests. ${ }^{110}$ (3) Of the American cases remaining after the English cases are eliminated, few involved commercial problems. The credit cases were with England. In South Carolina, for example, one of the diversity cases involved a drunken brawl and another involved slave stealing. ${ }^{120}$

To understand the judiciary of 1787 , one must of course understand the country, and the country was growing and changing so quickly that the commercial America of 1800 was substantially different from the commercial America of 1780 . When the Constitution was drafted the underlying economic developments which we assume when we speak of diversity jurisdiction today had barely begun to exist. First, there was substantial interstate and intercolonial trade in the period before $x 780$, but both in volume and in dollar value it was less significant than the West Indian trade or the European trade. ${ }^{121}$ Second, the intercolonial trade was predominantly of a very

${ }^{119}$ Hyde \& Co. v. Bradford's Ex., I H. \& McH. 82 (Md. 1730); Brent's Lessee v. Tasker, id. at 89 (1737); Black v. Digges's Ex., id. at 153 (1744); Burk v. M'Clain, id. at 236 (1766). The last case discusses the relation of various problems of debt collection to convenience of trade between England and Maryland.

${ }_{120}$ Genay v. Norris, I Bay 6 (S. C. 1784 ); Porter v. Dunn, id. at 53 (1786 or 1787 ).

121 It is extremely difficult to find statistical analyses of early trade, because not enough statistics were kept. The first important contemporary statistical study of trade is TeNCF COXE, A VIEw of THE Unted States (1794). Coxe was Commissioner of Revenue. However, most of his data begins about 1790, and he has more data on exports and imports than interstate trade. A statistical reconstruction has been done in the Carnegie Instution publication by EMORY R. Jornson and others, History of Domestic and Foreign Comarerce of the United States (I915). The materials vol. I, II2-I2I and I62174, and particularly the analysis at I7I, with tables, present the best picture of trade. Other significant studies are Timothy Pitkin, A Statistical View of the Commerce of the United States (i835); and two Columbia University studies, Robert A. EAst, Business ENTERPRise in the AMerican Revolutionary Era (1938), and Michael Kraus, Intercolonial Aspects of American Culture on the Eve of the Revolution (1928). The German pamphlet, Shirach, Historisch-Statistiche Notiz DER Grossbritraniscien Colonien in AMERIKA (Frankfurt and Leipzig, 1776), has the advantage of contemporaneity although its author had not been in the Colonies. 
local variety. Thus New York was the harbor for New Jersey and Connecticut, and Philadelphia shipped the produce of Delaware. ${ }^{122}$ The national business enterprise of the sort that now utilizes diversity jurisdiction did not exist. In 1780 the colonies had no banks, and, as Tables I and 2 show, the insurance business had scarcely begun to affect litigation. ${ }^{123}$ Though land speculation was large business, its days of big litigation were largely in the offing. Third, interstate transactions were principally on a barter, paper-money; or very short-term basis. There was credit in the colonies both before and after the Revolution, but it was credit from England. ${ }^{124}$

Thus the actualities of trade coupled with the record of litigation combine to give this description: There was very little commercial diversity litigation among the colonies prior to 1787 . What there was arose largely within confined marketing districts in which economic lines deviated slightly from state lines. National commercial litigation involving far-flung interests was around the corner after the Revolution. The cotton gin and the first cotton mill, large-scale banking and large-scale insurance were still in the future in 1787 . There was some, but only a little, preRevolutionary hostility in litigation to the commercial interests of other states, but this may well have been because the occasion for hostility rarely arose. The typical case was still $A$ v. $B$ for a cow.

To this point, the subject of diversity has been approached as though there were a rational distinction between anti-British-creditor hostility and interstate hostilities.

202 This is not to say that there was no long-distance intercolonial trade. Boston and Newport merchants traded all over the colst, Johisson, supra note 121, at 170; and products such as paper and books went from Philadelphia to the South. See Hanna, The Trade of the Delaware District Before the Revolution, 2 SMITH Colt. Studies IN Hist. 241-245 (I916-17), for a statement of the nature of trade districts, and $i d$. at $26 \mathrm{I}$ et seq. on trade from Philadelphia to the South. But Hanna concludes that the West Indian trade was "the basis of the commercial life of this district."

Some colonies had a higher proportion of intercolonial trade than others because they were in marketing districts pivoting on neighboring cities. New Hampshire, New Jersey, Connecticut, and Delaware are examples. Johsson, op. cit. stupra, note 121, at 168 . It will be noted from Table 3 that Connecticut had an unusually large proportion of diversity cases, analyzed by Friendly, stupra note 106, at 493, 494. It is doubtless no accident that the one concrete example Madison gave the Virginia convention of the necessity of diversity jurisdiction was that "before the war, New York was to a great amount a creditor of Connecticut. While it depended on the laws and regulations of Connecticut, she might withhold payment. If I be not misinformed, there were reasons to complain." 3 ELzrotr 535 (italics added).

${ }^{123}$ The Bank of North America, a Morris enterprise but with national participation, was founded in 1781. The Bank of New York and the Massachusetts Bank followed in 1784 . A sccond series of banks began shortly after the adoption of the Constitution. For discussion see East, op. cit. supra note I21, c. XIII, Commercial Banks, 1781-92. Small insurance offices began in New York and Philadelphia aboiut 1760 and began to achieve importance during the war; id. at 69-71. By 1834 , there were 503 banks with a capital of $\$ 203,000,000$; PITKIN, op. cit. stupra, note I21, at 460 .

124 Colonial credit and investment practices showing that credits were scattered but not unknown are described in EAST, op. cit. stipra, note 121 , at $15-23$. But as Franklin said in his Address on a Commercial System, May II, I787, "In this country the consumer's money follows the delivery of the manufacture, therefore less capital is required." CoxE, op. cit. stspra, note $\mathrm{I21}$, at $x 9$. He also refers to European credit, speaking of "the prodigious credit there given to our merchants on the return of peace." Id. at 26,27. As Johnson, op. cit. stipra, note 121, at 126, puts it, ". . . American commerce, not only in colonial times but after the Revolution, was carried on very largely by the aid of British capital. There was a scarcity of capital in America, and merchants in the United States traded with British merchants whose supply of capital enabled them to extend the necessary credit to American traders after, as well as before, $1783 . "$ 
For the post-1 763 period of strain between the colonies and England, this distinction is sensible; but in earlier periods there was no anti-British-creditor sentiment which could not just as well have been anti-Philadelphia-banker sentiment had there been Philadelphia banks. The Philadelphia Convention dealt with both together by providing federal jurisdiction both for the extra-state suitors and the extra-national suitors. Madison said in the Virginia convention, speaking of local courts, "We well know, sir, that foreigners cannot get justice done them in these courts, and this has prevented many wealthy gentlemen from trading or residing among us."12J $\mathrm{He}$ and his colleagues obviously thought of national and international diversity together.

The real key to the diversity clause lies in the optimism of the founders, an optimism which escapes the label "fantastic" because the dreams so often came true. The members of the Convention did a great deal of anticipating, and on many subjects besides diversity jurisdiction. They anticipated manufacture and trade within the United States on an unknown but vast scale. One of the principal objects of the Convention was to open a path for that expansion. ${ }^{126}$ If Robert Morris could buy five million acres of New York, he could anticipate gigantic interstate trade. If the Founding Fathers could anticipate the industrial and commercial revolution, already beginning, they could anticipate some of the obstacles to the success of the concomitant business enterprise. The diversity clauses were based on that dual anticipation more largely than on experience. Actual experience in quantity was lacking because the economic order necessary to that experience had not yet come fully into existence.

At the same time there was an independent but related factor of judgment that the federal courts would be more sympathetic to business interests than the state courts. There was probably a sentiment that land investments would be safest in the hands of federal judges. It is unnecessary to restate here the materials covered by Friendly. Suffice it to say that independent reexamination of the subject results in the conviction that one heavy factor in establishing diversity jurisdiction was the consideration of the comparative class bias of the two systems.

There was probably a third factor of efficiency. Poorly paid, short-term state judges were, in the minds of the Philadelphia Convention, sometimes incompetent and inept. ${ }^{127}$

${ }^{295} 3$ Ersiort 583 .

${ }^{220}$ In studying the Constitution it should never be forgotten that its first object was to promote commerce. The delegates originally gathered at Annapolis were directed "to take into consideration the trade and commerce of the United States; to consider how far a uniform system in their commercial intercourse and regulations might be necessary to their common interest and permanent harmony." I ExIroTr II7.

${ }^{127}$ Madison speaks of the "tardy, and even defective, administration of justice . . . in some states." 3 Erurotr 533. The foregoing discussion in this article shows that on occasion the state courts were not efficient. Irritated counsel in Brown v. Van Braam, 3 Dall. 344, 350 (U. S. 1797), said, "If, disdaining to sanctify the errors of clerks, and the blunders of yearlings (to whom too often the business of keeping and making up a record is confided) the Federal Courts should discountenance and reject the errors and irregularities of the practice of the State Courts, every suitor would gratefully acknowledge 
To summarize, the diversity jurisdiction in the federal Constitution may fairly be said to be the product of three factors, the relative weights of which cannot now be assessed:

I. The desire to avoid regional prejudice against commercial litigants, based in small part on experience and in large part on common-sense anticipation.

2. The desire to permit commercial, manufacturing, and speculative interests to litigate their controversies, and particularly their controversies with other classes, before judges who would be firmly tied to their own interests. ${ }^{128}$

3. The desire to achieve more efficient administration of justice for the classes thus benefited.

IV

\section{Conclusion}

In the history of federal jurisdiction and federal courts, many questions remain unanswered: If Madison and Wilson had not devised their "Great Compromise" at Philadelphia, would we today be without lower federal courts? If it had not been for the necessity of settling international admiralty disputes, would either the Convention or the Congress of 1789 have created a federal lower court system? In other words, is the domestic federal legal system predominantly a byproduct of our international relations? Why-a mystery truly dark-why did the Congress of 1789 provide that appellate jurisdiction should be sufficient in federal question cases while there should be trial court jurisdiction in diversity cases? Why diversity at all? What is the relationship of particular economic interests to Article III? But enough of such a list; there is sufficient mystery left in the origins of the federal judiciary to keep a good many researchers busy for a long time.

the obligation." In I80I Hamilton, reviewing all the reasons for establishment of a federal judiciary, spoke of state courts "so constituted as not to afford sufficient assurance of a pure, enlightened, and independent administration of justice." 7 Hamilton, Works of HAMmLTON $76_{4}$ ( $185 \mathrm{I}$ ). (The phrase is of course ambiguous and was written in a new controversy, but the whole essay of which it is a part coincides to a considerable extent with Madison's clause-by-clause analysis, 3 Extiort 53 1-534.)

${ }^{128}$ The spirit desired is well indicated in the instructions of Justice Patterson to a jury while on circuit in Van Horne's Lessee v. Dorrance, 2 Dall. 304, 310, 3II (U. S. I795). The right of acquiring, possessing, and protecting property is spoken of affectionately as natural and inalienable. Indced, said Justice Patterson, "It is sacred." As a critic of the judiciary system put it, "The few, the well born, \&c. as Mr. Adams calls them, in judicial decisions as well as in legislation, are generally disposed, and very naturally too, to favour those of their own description." Lee, Letters of a Federal Farmer, in PAUL L. Ford, Paxphlets on the Constitution 316 (I888). 